Southern Methodist University

SMU Scholar

Anthropology Research

Anthropology

$12-2020$

\title{
Mexican obsidian on Maui: Hawaiian connection, harmonic convergence, or hokum?
}

\author{
Matthew Boulanger \\ mboulanger@smu.edu
}

Follow this and additional works at: https://scholar.smu.edu/hum_sci_anthropology_research

Part of the Archaeological Anthropology Commons, and the Geochemistry Commons

\section{Recommended Citation \\ Boulanger, Matthew, "Mexican obsidian on Maui: Hawaiian connection, harmonic convergence, or hokum?" (2020). Anthropology Research. 9. \\ https://scholar.smu.edu/hum_sci_anthropology_research/9}

This document is brought to you for free and open access by the Anthropology at SMU Scholar. It has been accepted for inclusion in Anthropology Research by an authorized administrator of SMU Scholar. For more information, please visit http://digitalrepository.smu.edu. 


\title{
Mexican obsidian on Maui: Hawaiian connection, harmonic convergence, or hokum?
}

\author{
Matthew T. Boulanger \\ Department of Anthropology, Southern Methodist University, United States
}

\section{A R T I C LE IN F O}

\section{Keywords}

Obsidian

Geochemistry

Lithic technology

Pre-Columbian trans-oceanic contact theories

Pseudoarchaeology

Conspiracy theory

\begin{abstract}
A B S T R A C T
In 2014, the television show America Unearthed (A \& E Networks) featured an episode discussing evidence for pre-Columbian contact between Polynesia and continental North and South America. Included in this "evidence" was a large spearpoint, allegedly found on the island of Maui. The show's host argues that the spearpoint is made on obsidian from central Mexico, and therefore represents evidence for direct contact between Polynesian and Maya peoples prior to the sixteenth century CE. A detailed analysis of the spearpoint, including geochemical sourcing, reveals that it is indeed made of so-called Pachuca obsidian from central Mexico; however, the size, shape, and lithic technology of the piece are consistent with easily obtainable modern creations. Two alternative hypotheses that account for all available evidence are offered to explain how this spearpoint may have traveled from Mexico City to Maui. In the absence of any other evidence supporting a pre- Columbian origin for this piece, it cannot be considered evidence of a Polynesian connection with continental North America.
\end{abstract}

\section{Introduction}

Claims of transoceanic contact prior to the "discovery" of the Americas in the late fifteenth century CE by Europeans have been a mainstay of pseudoarchaeology for almost as long as European colonizers and American colonials have sought to explain the ultimate origins of indigenous Americans. Most commonly, fringe historians suggest that voyageurs from the ancient Mediterranean world or western Europe crossed the Atlantic Ocean and colonized the Americas long before Leif Erikkson and Columbus. Other less common claims involve a trans-Pacific movement of people into South America, Mesoamerica, and even North America. Pseudoarchaeologists such as Barry Fell and Graham Hancock have presented various scenarios by which they see migrations or contact across the Pacific. These ideas often rest on a handful of isolated artifacts and/or generalized similarities amongst myriad cultures of the Americas and Oceania.

The idea of a trans-Pacific crossing has had its proponents within scholarly archaeology. Heyerdahl's (1950) Kon-Tiki experiment demonstrated that such a crossing (from Peru to Raroia) was possible. But simply because such an experiment is possible does not mean that it happened (e.g., Novick et al., 2020). Meggers et al. (1965) reported on what they interpreted as similarities between ceramics of the Valdivia culture of coastal Ecuador and the middle Jomon culture of western Japan (see also Ford, 1969). Yet, concerted archaeological research over the past 200 years has failed to provide any substantial material evidence for a trans-Pacific origin for any Native American culture. All evidence (archaeological, geological, and genetic) point towards a late-Pleistocene entrance into the Americas from Beringia; although, as discussed below, there is reasonable (though certainly not conclusive) evidence for much later contact between Polynesian seafarers and the inhabitants of coastal South America.
Nonetheless, the idea of a trans-Pacific discovery of the Americas remains a mainstay in the world of pseudoarchaeology. One such recent claim comes from television personality, author, and self-described forensic geologist Scott Wolter. In 2014, Wolter was the host of A\&E Networks' short-lived series America Unearthed, a show devoted to exploring supposed archaeological mysteries and uncovering supposed archaeological conspiracies. The list of (non)mysteries covered by Wolter is a Greatest Hits album of fantastic archaeology: the Tucson Artifacts, Giants in the Earth, America's Stonehenge, The Newport Tower, Hebrew artifacts in America, the Knights Templar. Readers familiar with the canon of American pseudoarchaeologial humbug will recognize that few of these topics are new. The claims about these topics have changed little over the past 100-200 years. Such stasis or stagnation of ideas and evidence is a common trait of pseudoscience. It bears pointing out that that nearly all of the supposedly "hidden" artifacts and ideas discussed on America Unearthed have been the subject of repeated and systematic inquiry by qualified experts, and that a preponderance of evidence suggests relatively mundane explanations for all of them (e.g., de Camp and de Camp, 1972; Feder, 2020; Fritze, 2002; McKusick, 1986; Steibing, 1984; Williams, 1991).

In fairness, Wolter does occasionally present archaeological information that is reliable, current, and informed by experts. However, in a formula similar to that used in other pseudoarchaeological media, he seamlessly blends factual information with assertions, his own interpretations, and conspiracy theory. The hook of America Unearthed is that the host ostensibly approaches these topics from the "scientific" perspective of a geologist. The reality is however, that what is presented on the small screen is just the pop-culture trappings of science. It is this veneer of science, along with CSI-like cutaways and montages, that set this particular show apart and distinguish it from other pseudoarchaeological claims that rely on patternicity (Shermer, 2011), pareidolia 
(Feder, 2020: 198-205), and "the Provocative Fact" (Randi, 1987: 129).

America Unearthed was canceled in 2015 after three seasons; however, in 2019 the Travel Channel revived the series. During preparation of this manuscript, Wolter stated during a podcast interview that a second season would not appear on the Travel Channel, but that it may reappear on another network (Colavito, 2020). Given that Wolter doesn't appear to be going away any time soon, and that he continues to spread and advocate pseudoarchaeological claims in books, on social media, and in a variety of other media outlets including various podcasts and Coast to Coast AM, it seems an apropos time to review some of the statements made in the previous incarnation of his show to provide curious viewers with much needed context and scientific data to evaluate his claims.

\section{2. "The Spearhead Conspiracy"}

Episode 13 of season 2 of the original incarnation of America Unearthed, entitled "The Spearhead Conspiracy", is an amalgamation of current archaeological ideas, fantastical pseudoarchaeological assertion, and a healthy dose of conspiracy theory. In this episode Wolter explores supposed evidence for Polynesian sailors reaching mainland North and South America prior to Columbus' landing in the Caribbean. Wolter couches the information in his episode as somehow being hidden, suppressed, or otherwise stifled by so-called mainstream archaeologists. Yet, for professional archaeologists, there is not much new here. There is currently a lively debate concerning whether Polynesians had contact with populations living on the western coast of South America, based largely on the distributions of, and linguistic terms for, sweet potato (Brand, 1971; Muñoz-Rodríguez et al., 2018; Roullier et al., 2013) and domesticated poultry (Thomson et al., 2014). Recently, Ioannidis et al. (2020) have documented a small Native American genetic component in some Polynesian populations, suggesting a "single prehistoric contact event between eastern Polynesian and Native American individuals" (2020: 576) most likely from coastal Ecuador. And, there are a very few archaeologists who entertain the possibility for brief contact between Polynesians and southern California Native Americans based on linguistic terms for, and formal similarities of, plank canoes (Jones and Klar, 2005; Klar and Jones, 2005). Given that at least some of this debate is occurring within high-level scholarly journals, and that summaries have been published in general-interest magazines, I believe it is fair to say that there is not a conspiracy to hide or dismiss evidence on the topic. Indeed, in the episode, Wolter speaks with numerous professional archaeologists to discuss their research on the subject. Wolter's own conclusions, however, differ significantly from anything that these professionals have argued.

The purpose of this report is not to provide a skeptical review of the America Unearthed episode-this has already been done by Colavito (2014a). Nor is my purpose to discuss the currently debated evidence for possible pre-Columbian interactions between Polynesians and Native Americans (i.e., genetics, sweet potatoes, chickens, and plank canoes). Nor is it to evaluate Wolter's claim that the ca. 9000 year-old Kennewick Man remains are those of an early Polynesian explorer. A cursory understanding of the timing of Polynesian expansion-as well as recent ancient DNA studies - conclusively demonstrates that this is decidedly not the case (Rasmussen et al., 2015). Rather, I address a new piece of purported evidence that Wolter highlights for approximately one-third of his episode: a roughly $8 \times 6 \mathrm{~cm}$ triangular piece of obsidian, clearly worked by human hands, supposedly found in Hawai ' $i$, and possibly made of Mexican obsidian. In Wolter's view, this piece of obsidian may be proof that ancient Polynesians had direct contact with the Maya of southern Mexico and the Yucatan Peninsula.

Below, I provide a brief summary of what is known about the archaeological context of this artifact, its provenance since being removed from the ground, and the claims made about it by Wolter on
America Unearthed. I then discuss the results of formal/typological, technological, and geochemical studies of the artifact, and what the resulting data suggest about the age of the artifact, where it comes from, and ultimately how it may have come to be found on an island in the middle of the Pacific Ocean.

\section{3. "All we want are the facts, ma'am"}

In 2009 a group of hikers in Haleakalā crater reportedly came across a large triangular obsidian artifact (Fig. 1) lying on the ground surface ${ }^{1}$ (Pignataro, 2014: 10). One of the hikers reports that the piece was covered with mud, and that after picking it up he cleaned it with rubbing alcohol from his first-aid kit. The hikers took the obsidian piece with them and claim to have reported it to National Park Service (NPS) personnel the following morning. The individuals who took the piece state that a representative from the NPS expressed skepticism regarding their find and encouraged them to return it to the park. Rather than doing so, the hikers chose to keep the piece for themselves. One of the hikers made the choice to have the piece drawn as a tattoo on his chest; the other placed it inside his "martial arts weapons altar" as a keepsake (Pignataro, 2014: 10).

Roughly a year later the hikers showed the specimen to Dr. Janet Six, an archaeologist at University of Hawai 'i Maui College (Pignataro, 2014). At some point between 2010 and 2013, Six showed the spearpoint to students in one of her classes (Colavito, 2014b, 2014c). One of these students contacted America Unearthed to request that Wolter investigate the specimen as possible evidence for pre-Columbian contact between Polynesia and the North American continent. The NPS, after receiving an application for a commercial filming permit in 2013 to film in Haleakalā National Park, contacted the hikers who had found the spearpoint, and ultimately took the specimen back into their custody (Pignataro, 2014). My involvement in this story began shortly after these events when the University of Missouri Research Reactor Archaeometry Laboratory (MURR) was contacted to provide an independent analysis of the provenance (geological source), approximate age, and technology of the specimen. What follows is a summary of my findings based on a firsthand examination of the piece over the course of several days in March 2014, and is a distillation of a technical report provided to the NPS.

\subsection{Technology of the specimen}

The specimen is a bifacially worked triangular stemmed point, made of a greenish obsidian that has a distinctive golden sheen. The size and mass (Table 1) of this piece suggest it is too large to be used effectively as the tip of an arrow or an atlatl dart (Lyman et al., 2008; Shott, 1996; 1997; Thomas, 1978; VanPool, 2006). From a lithic-technology perspective, the specimen can be described as a large, triangular, stemmed biface; however, the colloquial functional descriptor "spearpoint" seems not entirely inappropriate. Analyses presented below, however, indicate this piece shows no evidence of having been produced or used as a functional tool.

Many aspects of the Haleakalā spearpoint's condition and mode of production are inconsistent with pre-Columbian artifacts. There are numerous crushed plates within flake scars on the specimen. These are portions of the rock that are incompletely removed during manufacture and that adhere to the specimen because of surface tension or because of a small lip not completely fractured during production (Fig. 2). These plates can be easily removed with a slight amount of pressure such as thermal expansion/contraction, or abrasion due to weathering. Because they are easily removed by a variety of use-related and post-depositional processes, a large number of crushed plates on a lithic specimen is a hallmark of recent (i.e., modern) flaked-tool production. 

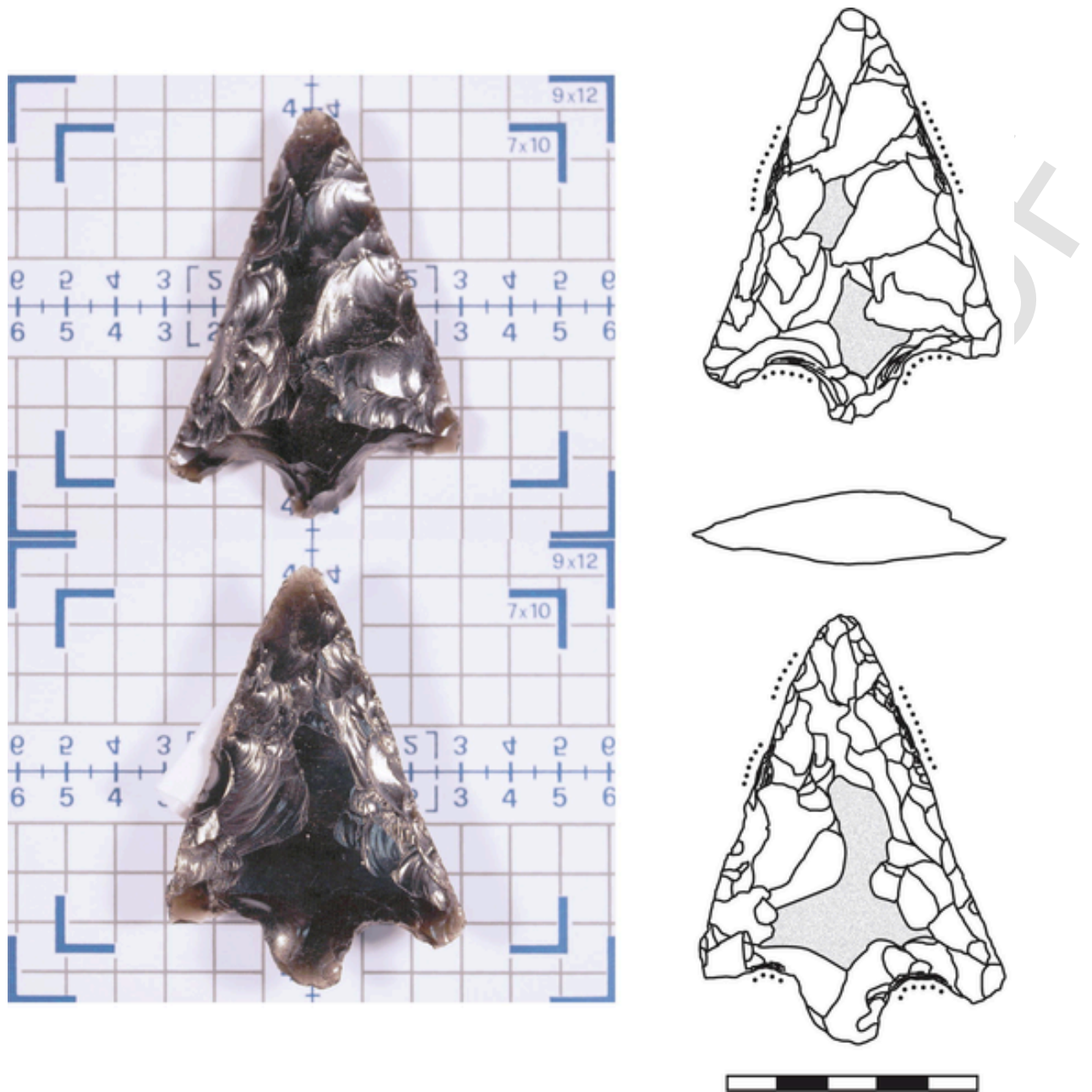

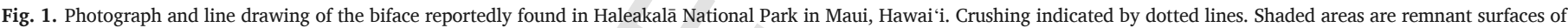
the flake on which the point is made. [Low-resolution image for review purposes]

Table 1

General measurements of the obsidian biface reportedly from Haleakalā National Park. All measurements in $\mathrm{mm}$.

\begin{tabular}{ll}
\hline Dimension & $\mathrm{mm}$ \\
\hline Max. Length & 81 \\
Max Width & 59 \\
Thickness & 17 \\
Length of Edge 1 & 77 \\
Length of Edge 2 & 73 \\
Medial Length & 68 \\
\hline
\end{tabular}

Flake scars on the spearpoint are characterized by significant crushing (Fig. 2) and a generally short and broad shape. These are characteristics of production with a single hard percussor, such as a hammer stone (Andrefsky, 2005; Odell, 2004; Whittaker, 1994). Edges of the piece exhibit a large number of step and hinge fractures, and the basal notching appears to be executed almost entirely by crushing. Step and hinge fractures such as those observed on the specimen result from failure of energy applied during knapping to propagate through the stone to produce a feathered terminal edge (Andrefsky, 2005; Cotterell and Kamminga, 1987; Odell, 2004; Whittaker, 1994). And crushing - as opposed to controlled flaking-is a quick way to remove mass from an obsidian flake, but it is rarely seen in pre-Columbian productions because it is uncontrollable and often leads to other problems during production. Such problems include the accumulation of step and hinge fractures near the margins of the tool, and these are numerous on the Haleakalā point. Neither fine-scale finishing work nor retouch/ resharpening is evident on any of the specimen's edges (Fig. 2). No evidence of a "carefully serrated edge" (Colavito, 2014c) is observable on the piece.

The spearpoint is made on a large thick flake of obsidian, and there is no evidence of attempts at bifacial thinning on the specimen. No flake scarring is evident across the center line of the specimen at its widest point. These areas are visible as broad flat surfaces with no flake scarring or ridges (Fig. 1) leaving surfaces original to the flake on which the point is made. The absence of thinning, combined with a large concentration of step and hinge fractures has left a significant bulge on the dorsal side.

All of the above noted technological features suggest a relatively rapid production sequence using a single hammer/percussor. No evidence for controlled flake removal is evident, and there is a great deal of evidence pointing to uncontrolled flaking, inconsistent applied force in flake removal, and a failure to understand how to use the angle at which force is applied to produce long thinning flakes up to or across the piece's midline. In a nonspecialist's terms: The flaking technology evidenced on the Haleakalā specimen is unskilled, and suggests a production more concerned with producing a general shape than with a functional tool. In numerous ways, the Haleakalā specimen does not show the technological hallmarks of undisputed prehistoric obsidian artifacts that were intended for use. 

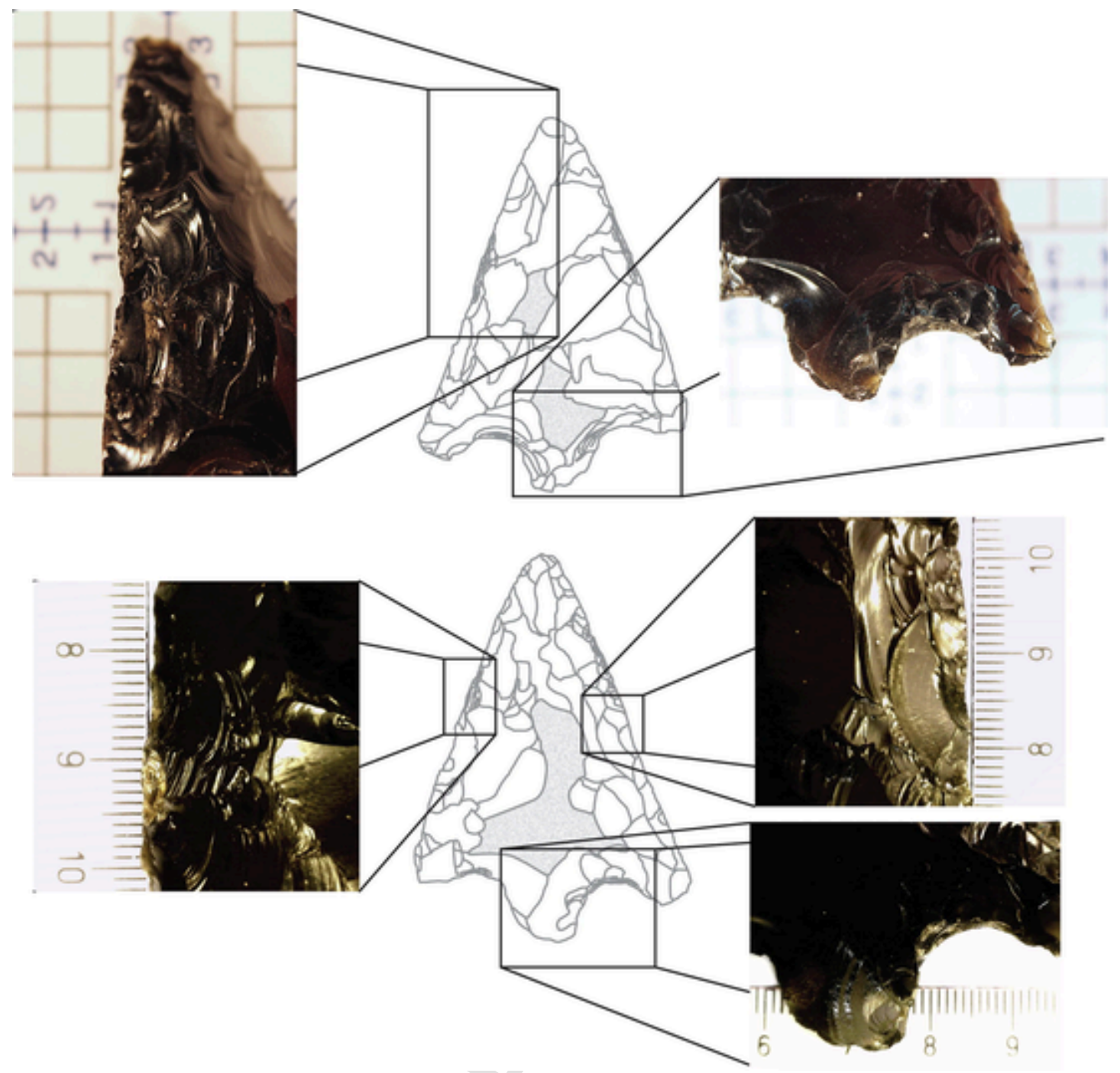

Fig. 2. Selected zones of the biface showing remnant crushed plates, crushing and step/hinge fracturing. [Low-resolution image for review purposes]

\subsection{Condition of the specimen}

The Haleakalā obsidian piece is exceptionally clean. Scanning of the edges and flake scars under $\leq 100 \times$ magnification reveals no accumulations of sediment in the cracks and crevices that are characteristic of flaked-stone tools recovered from archaeological deposits. Photographs and a video shown in the America Unearthed episode purportedly show the piece at the time of its finding. In those images, the specimen also appears to be free of any occluding sediment, and it appears essentially identical to the condition it was in when I examined it five years after its discovery. In short, the piece shows no evidence of having ever been "covered in mud" as reported by the finders (Pignataro, 2014). As noted above, the finders reportedly cleaned the specimen with rubbing alcohol immediately upon finding it; however, the absolute absence of any occluding sediments in the (literally) thousands of microscopic grooves, fissures, and cracks of a flaked-stone artifact suggests that either the piece has never been covered in mud, or that it has been rigorously cleaned through the use of an ultrasonic bath.

It is also notable that no weathering effects (e.g., scratching, crazing, polish) or patina are observable on the specimen. No amount of cleaning (with alcohol or otherwise) would remove weathering effects from an obsidian artifact, and the absence of any abrasion or patina on the piece suggests that it has not been exposed to the elements-buried or otherwise-for any appreciable length of time.

\subsection{Geological source}

The obsidian specimen was analyzed using a Bruker Tracer III-V handheld X-ray fluorescence spectrometer. The Tracer III-V uses a Rh-based X-ray tube operating at $40 \mathrm{kV}$ and a thermoelectrically-cooled silicon detector. A suite of over 40 well-characterized obsidian specimens is used to create a calibration routine for the Tracer III-V (Glascock and Ferguson, 2012), and this calibration has been independently evaluated and verified (Speakman, 2012). Mean elemental-abundance values from multiple characterization studies conducted by neutron activation analysis (NAA) and inductively coupled plasma-mass spectrometry (ICP-MS) were used for the obsidian calibration specimens. The Haleakalā spearpoint and representative specimens from geological sources of obsidian were analyzed on the Tracer III-V for at least three minutes. This protocol and the obsidian calibration routine permit quantification of the following major, minor, and trace elements: $\mathrm{K}, \mathrm{Ti}, \mathrm{Mn}, \mathrm{Fe}, \mathrm{Zn}, \mathrm{Ga}, \mathrm{Rb}, \mathrm{Sr}, \mathrm{Y}, \mathrm{Zr}, \mathrm{Nb}$, and Th. In addition to the Haleakalā specimen, I analyzed pieces of obsidian obtained directly from the only known prehistorically mined obsidian source on Hawai ' $i$, the Pu'u Wa'awa'a source of the Hualalai Volcano, as well as from sev- 
eral other known sources of greenish obsidian in central and western Mexico.

The composition of the Haleakalā specimen, taken from both sides of the artifact is presented in Table 2, along with the compositions of obsidian-source samples. Based on its geochemical composition, the Haleakalā specimen is chemically distinct from both the $\mathrm{Pu}^{\prime} \mathrm{u}$ Wa'awa'a obsidian source on Hawai ' $i$ and from other known sources of green obsidian used prehistorically in Mesoamerica (Figs. 3 and 4). At present, the only known source of prehistorically used obsidian that matches the chemistry of the Haleakala specimen is the Sierra de Pachuca 1 source in Hidalgo, Mexico, roughly $90 \mathrm{~km}$ northeast of modern-day Mexico City.

\subsection{The Sierra de Pachuca obsidian source}

The Sierra de Pachuca obsidian source (aka Sierra de las Navajas) is a ca. $250 \mathrm{~km}^{2}$ volcanic deposit within which three chemically distinct varieties of obsidian occur. One of these varieties, a distinctive green obsidian with a gold hue referred to as Sierra de Pachuca 1 or Las Minas Green, was extensively mined during and after the rise of the Teotihuacán state between 100 BCE and 550 CE (Ponomarenko, 2004), and appears to have formed the basis for large-scale craft production at Teotihuacán (Hirth et al., 2019). Extensive pre-Columbian mining operations led to it becoming the one of the largest and most-widely traded obsidians among the major sociopolitical centers of the Central Mexico Highlands, including the states of Teotihuacán, Tula, and Tenochtitlán. In the Central Highlands and the Basin of Mexico, Sierra de Pachuca 1 obsidian typically represents $>20 \%$ of obsidian in archaeological assemblages during the late Classic and Postclassic periods (ca. 650-1520 $\mathrm{CE}$ ). Artifacts made on Sierra de Pachuca 1 obsidian have been found as far north as Oklahoma (Barker et al., 2002) and as far south as Honduras and El Salvador (Braswell, 2010; Braswell et al., 1994), but the frequency and physical size of Pachuca obsidian in archaeological assemblages decays nearly exponentially with distance from the source. Thus, although Pachuca obsidian is occasionally found at Maya sites in Guatemala, Honduras, and the Yucatan, it is encountered at very low frequencies (less than 1\%) and in very small artifact sizes (e.g., Braswell et al., 1994; Braswell, 2010; Spence, 1996).

In the America Unearthed episode Wolter suggests that if the Haleakalā specimen is genuine, then it is evidence of interactions with Andean peoples of South America; the Chumash of modern-day California; and/or the Maya of southern Mexico, Guatemala, and Honduras. These are ethnically distinct peoples living across two continents, and none of these people are known for their use of Sierra de Pachuca obsidian-which crops out in the central Mexico Highlands. An extensive literature review failed to identify any evidence of Pachuca obsidian in pre-Columbian contexts in California or in South America, and whereas a small amount of Pachuca obsidian has been documented from the Maya region, other obsidian sources were by far the most commonly used in the Maya realm. If the piece is genuinely pre-Columbian, it would most likely be evidence for contact between Polynesians and peoples native to the Basin of Mexico at the time of Polynesian expansion across the Pacific (300 CE at the earliest, but more likely ca. 600-1200 $\mathrm{CE})$, not Maya, Chumash, or Andean peoples.

\section{Discussion}

The chemical composition of the Haleakalā spearpoint leaves no doubt that the specimen is made on obsidian from the Sierra de Pachuca 1 source, obtainable only in the Sierra de las Navajas volcanic deposit in Hidalgo, Mexico. Although the specimen is vaguely similar to late stage preforms and Teotihuacan dart points, it is overly large and thick in comparison to archaeological specimens (e.g., Carballo,
2007). Moreover, the quality and style of the knapping and the form of the specimen are inconsistent with obsidian artifacts manufactured in Mesoamerica and Central America during the time at which Hawai ${ }^{~} \mathrm{i}$ was colonized by Polynesian seafarers. The knapping technology suggests a hurried production, with concern primarily for general shape and appearance. The spearpoint shows no attributes that suggest it was produced as a functional prehistoric artifact, and the absence of any fine-scale work - and the ubiquity of indicators of an expedient "roughing out" process - excludes this piece from consideration as an item produced for prestige or ceremonial purposes as suggested by Wolter in the America Unearthed episode (e.g., compare with Spence, 1996: Fig. 2). Results of my analyses strongly suggest that the Haleakalā specimen is of recent production. Thus, it is necessary to explore how and why a spearpoint like this, made on Mexican obsidian, could have found itself in Hawai' $\mathrm{i}$.

\subsection{Modern availability of Pachuca obsidian}

Sierra de Pachuca 1 obsidian is mined at an almost industrial level today. The stone is used primarily in support of the production and sale of tourist-trade items throughout Mexico (Ponomarenko, 2004). Tourist souvenir "arrowheads" made on Pachuca obsidian can be purchased at or near most major archaeological sites around Mexico City, and at one time were available for purchase at the Mexico City airport. The Pachuca obsidian source is a major resource for the tourist trade in and around Teotihuacán, and there is even an annual obsidian-craft festival (the Festival Internacional de la Obsidiana) at Teotihuacán. Internet marketplaces make it relatively easy to purchase ersatz "arrowheads" that are made on Pachuca obsidian, and modern flintknappers can find numerous on-line suppliers of the material to produce their own crafts at home. Indeed, readers can find a YouTube video (http:// www.youtube.com/watch?v = MKMnkWeiy-Y) showing one Mexican artisan living at the Pachuca obsidian source and producing a relatively large bifacial knife that he states will be sold for 12 pesos. This video is relevant in the present context as it shows how a vaguely pre-Columbian-looking "artifact" may be produced in under 10 min using a rapid, uncontrolled hard-hammer percussion technique focused solely on general outline and shape. This is exactly the technique of manufacture suggested by a detailed examination of the Haleakalā specimen. Also of note is that despite less than 10 min of intensive flaking, none of the flakes produced by the artisan reach or cross over the midline of the widest portion of the piece (Fig. 5B). As discussed above, this is because the knapper is using a single hard percussor, is relatively unconcerned with thinning the piece, and generally is not adjusting the angles of his blows. These traits have also been observed on another obsidian specimen that I have analyzed, this one being a confirmed tourist-trade item (Fig. 5C) purchased in Mexico-and also made on Sierra de Pachuca 1 obsidian (Boulanger et al., 2007).

\subsection{From Mexico to Hawai $i$}

How did this modern spearpoint, made on obsidian from near Mexico City, come to find itself on the Island of Maui, roughly $6000 \mathrm{~km}$ (3700 mi) from its source? I can think of at least two possibilities here. The first comes from a comment made by Janet Six (Pignataro, 2014; Colavito, 2014b; 2014c): The piece may have been deposited in Haleakalā during the 1987 "Harmonic Convergence." The Harmonic Convergence was a New Age spiritual event held on August 16 and 17, 1987, during which people gathered at various "power points" around the globe for chanting, meditation, prayer, and other New Age spiritual activities (Ivakhiv, 2005; see also Feder, 2010: 134-135). Both Teotihuacán and Haleakalā were among the various supposedly sacred sites at which people gathered (Sullivan, 1987; Weisman, 1987). One aspect of the New Age activities at some of these sites included the 
Table 2

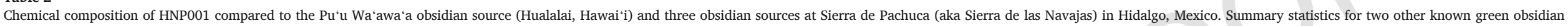
sources, both on the Pacific Coast of Mexico, are shown: Volcan Navajas 2 in Nayarit, and La Joya in Jalisco. All data generated by X-ray fluorescence at the MURR Archaeometry Laboratory.

\begin{tabular}{|c|c|c|c|c|c|c|c|c|c|c|c|c|c|}
\hline & $\mathrm{n}$ & $\mathrm{K} \%$ & $\mathrm{Ti}$ & Mn & $\mathrm{Fe} \%$ & $\mathrm{Zn}$ & $\mathrm{Ga}$ & $\mathrm{Rb}$ & $\mathrm{Sr}$ & $\mathrm{Y}$ & $\mathrm{Zr}$ & $\mathrm{Nb}$ & Th \\
\hline $\begin{array}{l}\text { HNP001 } \\
\text { (dorsal) }\end{array}$ & 1 & 3.498 & 799 & 1096 & 1.536 & 238 & 28 & 198 & 4 & 107 & 1025 & 91 & 20 \\
\hline $\begin{array}{l}\text { HNP001 } \\
\text { (ventral) }\end{array}$ & 1 & 3.520 & 844 & 1146 & 1.606 & 214 & 31 & 202 & 4 & 120 & 1062 & 92 & 20 \\
\hline $\begin{array}{l}\text { HNP001 } \\
\mu \\
\text { Hawaiian S }\end{array}$ & $\begin{array}{l}2 \\
\text { arce }\end{array}$ & 3.509 & 821 & 1121 & 1.571 & 226 & 30 & 200 & 4 & 114 & 1043 & 91 & 20 \\
\hline $\begin{array}{l}\text { Pu'u } \\
\text { Wa'awa'a } \\
\text { Hualalai, } \\
\text { Hawai ' }{ }^{\prime} \text { ' } \\
\text { Sierra de }\end{array}$ & huca, & $3.442 \pm 0.066$ & $1333 \pm 107$ & $2484 \pm 153$ & $2.578 \pm 0.082$ & $214 \pm 20$ & $27 \pm 2$ & $133 \pm 5$ & $31 \pm 2$ & $59 \pm 3$ & $1061 \pm 34$ & $139 \pm 6$ & $11 \pm 2$ \\
\hline $\begin{array}{l}\text { Sierra de } \\
\text { Pachuca } \\
1\end{array}$ & 45 & $3.583 \pm 0.064$ & $853 \pm 109$ & $1093 \pm 91$ & $1.64 \pm 0.045$ & $230 \pm 17$ & $28 \pm 3$ & $204 \pm 8$ & $4 \pm 1$ & $116 \pm 5$ & $1083 \pm 28$ & $94 \pm 3$ & $21 \pm 2$ \\
\hline $\begin{array}{l}\text { Sierra de } \\
\text { Pachuca } \\
2\end{array}$ & 8 & $3.567 \pm 0.073$ & $913 \pm 115$ & $780 \pm 65$ & $1.459 \pm 0.038$ & $142 \pm 12$ & $24 \pm 3$ & $125 \pm 3$ & $4 \pm 1$ & $90 \pm 4$ & $764 \pm 38$ & $58 \pm 3$ & $12 \pm 2$ \\
\hline $\begin{array}{l}\text { Sierra de } \\
\text { Pachuca } \\
3 \\
\text { Other Mexi }\end{array}$ & n Gree & $3.601 \pm 0.071$ & $897 \pm 79$ & $947 \pm 69$ & $1.456 \pm 0.096$ & $172 \pm 7$ & $27 \pm 4$ & $172 \pm 8$ & $5 \pm 1$ & $107 \pm 7$ & $886 \pm 40$ & $84 \pm 4$ & $20 \pm 2$ \\
\hline $\begin{array}{l}\text { Volcan } \\
\text { Navajas } 2\end{array}$ & 5 & $3.534 \pm 0.057$ & $1152 \pm 150$ & $1700 \pm 116$ & $4.781 \pm 0.106$ & $326 \pm 28$ & $34 \pm 5$ & $191 \pm 9$ & $13 \pm 1$ & $137 \pm 6$ & $1364 \pm 43$ & $133 \pm 1$ & $24 \pm 3$ \\
\hline $\begin{array}{l}\text { La Joya } \\
\text { USGS } \\
\text { RGM-1 }\end{array}$ & 23 & $\begin{array}{l}3.625 \pm 0.07 \\
3.544\end{array}$ & $\begin{array}{l}783 \pm 107 \\
589\end{array}$ & $\begin{array}{l}726 \pm 96 \\
447\end{array}$ & $\begin{array}{l}2.101 \pm 0.075 \\
1.228\end{array}$ & $\begin{array}{l}149 \pm 18 \\
66\end{array}$ & $\begin{array}{l}24 \pm 3 \\
13\end{array}$ & $\begin{array}{l}166 \pm 6 \\
133\end{array}$ & $\begin{array}{l}2 \pm 1 \\
88\end{array}$ & $\begin{array}{l}75 \pm 4 \\
18\end{array}$ & $\begin{array}{l}854 \pm 26 \\
189\end{array}$ & $\begin{array}{l}63 \pm 3 \\
7\end{array}$ & $\begin{array}{l}17 \pm 2 \\
14\end{array}$ \\
\hline $\begin{array}{l}\text { Certified } \\
\text { Values }\end{array}$ & & $3.64 \pm 0.18$ & $1600 \pm 200$ & $280 \pm 20$ & $1.32 \pm 0.05$ & $32 \pm 7$ & $14 \pm 2$ & $157 \pm 4$ & $110 \pm 10$ & 27.0 & $214 \pm 14$ & $10 \pm 4$ & $16 \pm 2$ \\
\hline
\end{tabular}




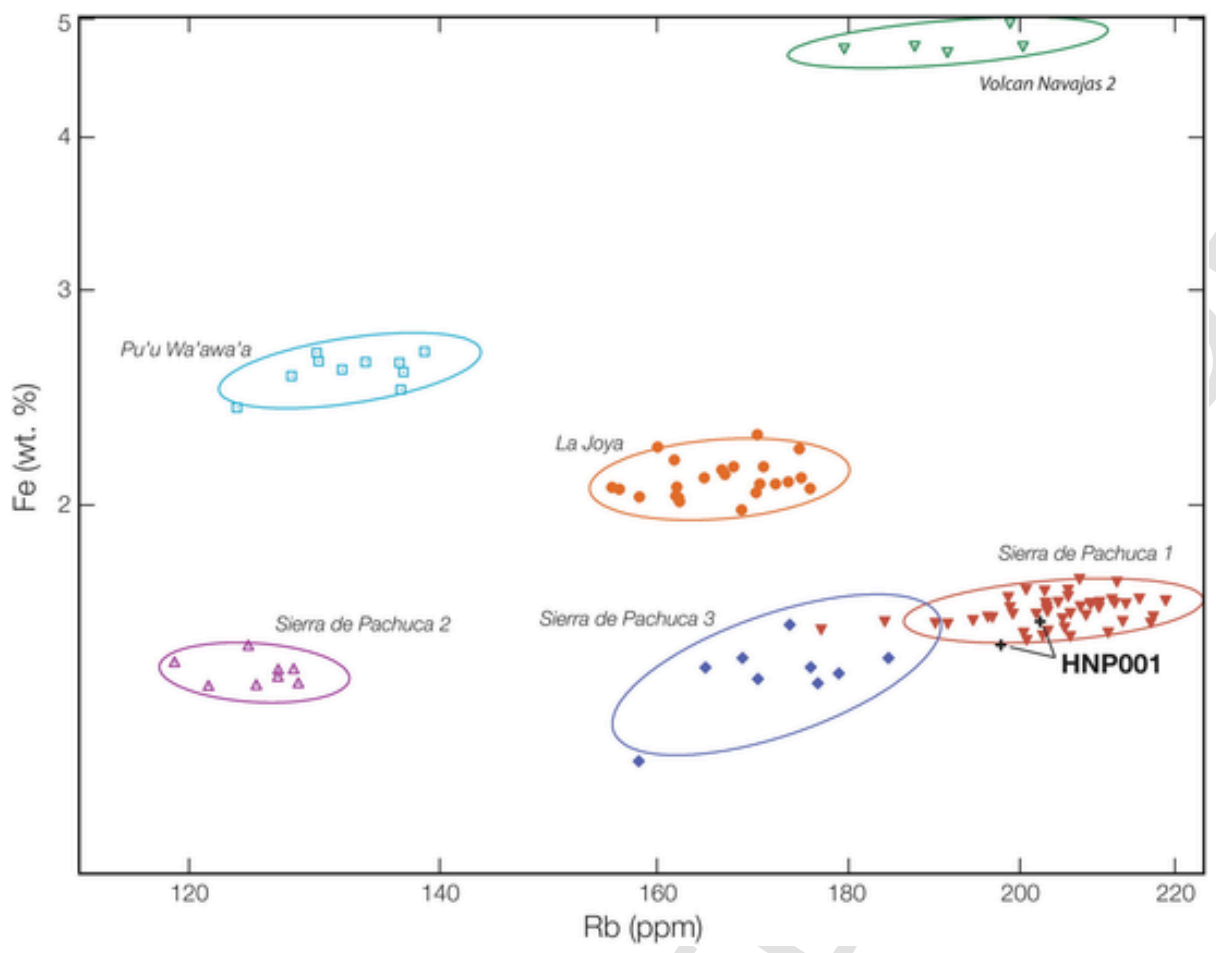

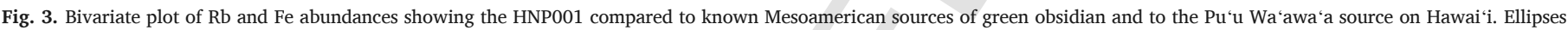

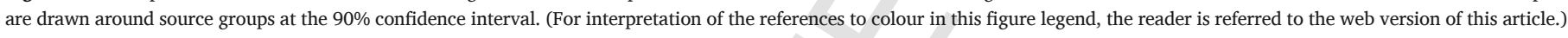

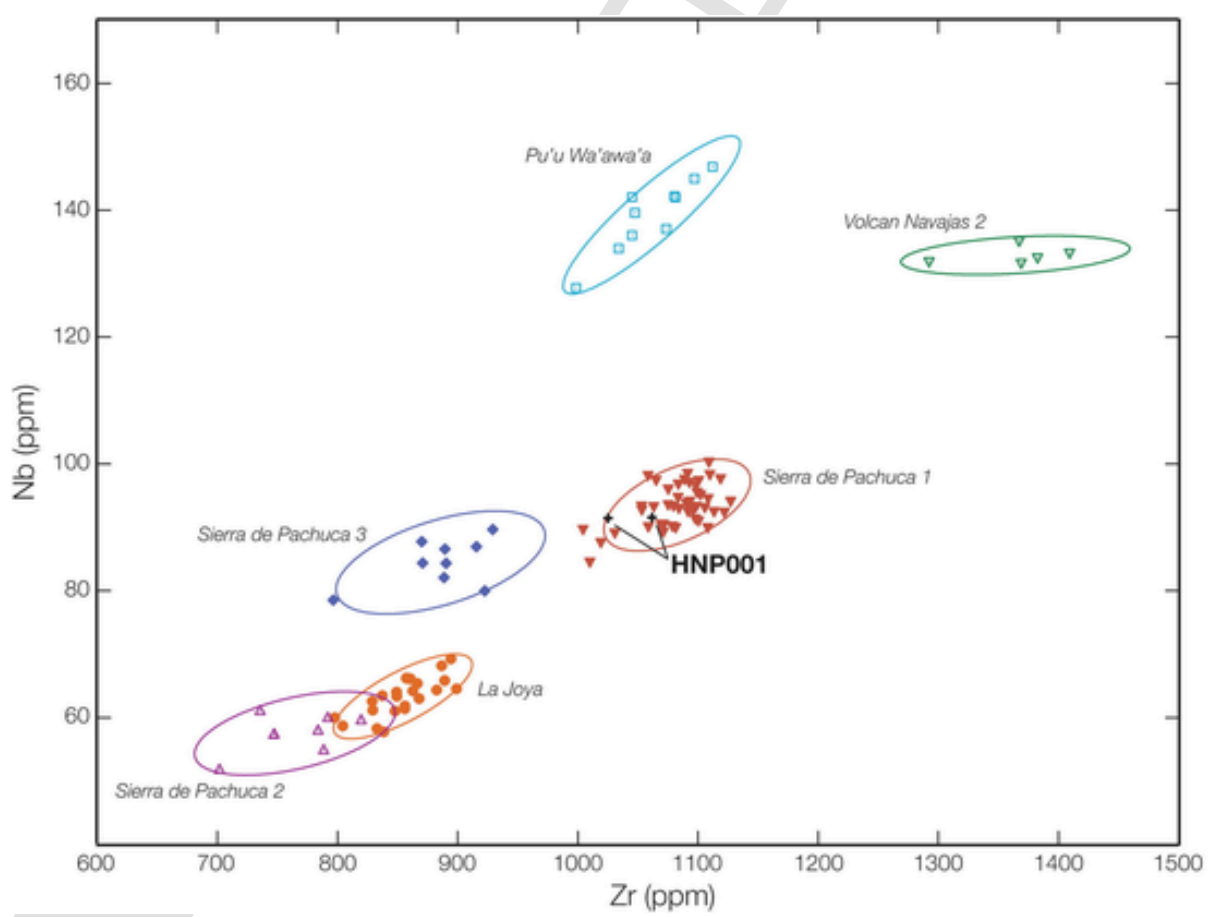

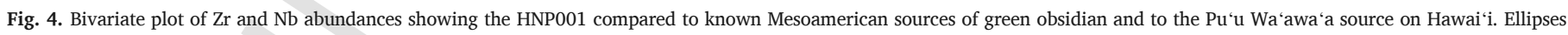

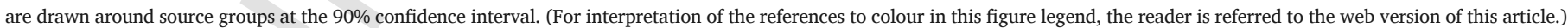

caching and/or burying of votive objects-including crystals and rocks-as offerings and to "recharge" their supposed power (Finn, 1997). These activities continue among New Age practitioners today at many of the same sites involved in the 1987 New Age event (Finn, 1997; Seguin, 2008). New Age practitioners assert that Pachuca obsidian provides spiritual, physical, and emotional healing power (Gienger,
2009). It seems more than reasonable to propose that some well-meaning New Age believer brought the obsidian spearpoint to Maui, and deposited it in the volcanic crater. Perhaps this happened during the 1987 Harmonic Convergence, or perhaps it happened afterwards. The point here is that New Age beliefs and practices suggest a reasonable alternative hypothesis as to how the piece arrived in Hawai' $i$. 

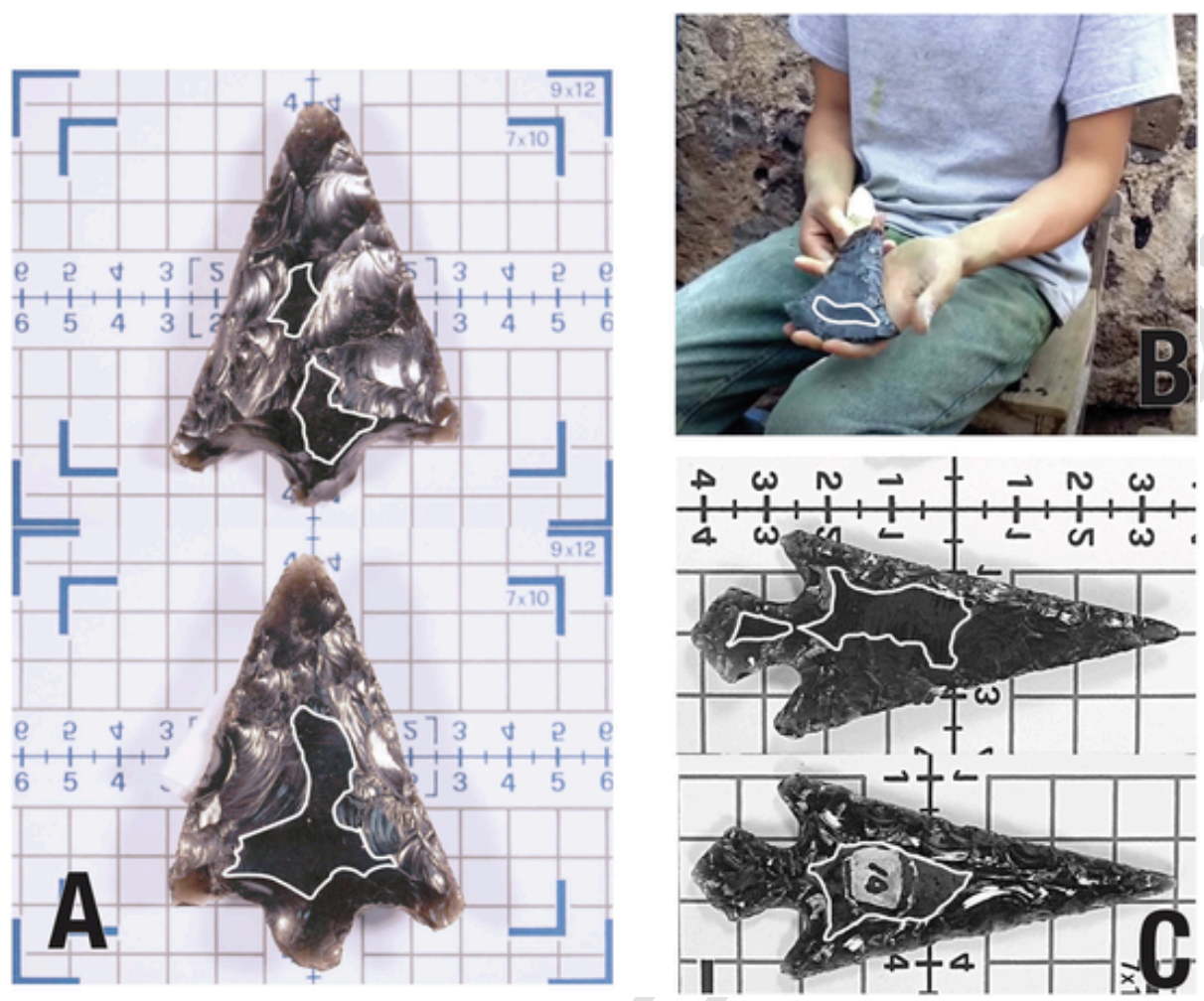

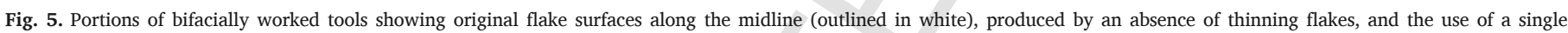

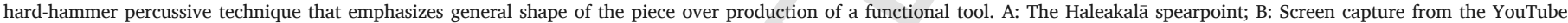

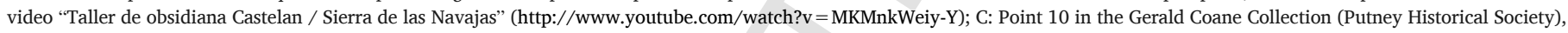
a tourist item made on Pachuca obsidian (after Boulanger et al. 2007: Figs. 2 and 3). Scale in cm. [Low-resolution image for review purposes]

A second possibility centers around the absolute lack of any evidence for the point being buried or "covered in mud," as the original finders reported. This highly specific detail of the story is conveyed by both men who reported finding the piece. In their own words, as quoted in Pignataro (2014: 10):

"I went off the trail, several hundred feet. There were piles of rocks, and this one stood out. I bend [sic] down to pick it up. It was a piece of obsidian, but when I started wiping it off, I saw that it was a spearpoint."

"He showed me a stone, covered in mud...I got my first aid kit and made the wrong the choice-I cleaned it with alcohol. You're not supposed to do that, because it makes dating an artifact difficult."

I find this account peculiar because, as I stated above, photographs and video shown in the episode of America Unearthed, supposedly taken at the time the spearpoint was found, show that it is completely clean. Moreover, the statement regarding "ma[king] the wrong choice" by cleaning it with alcohol because doing so "makes dating an artifact difficult" seems curious given that neither of the men who found the point are archaeologists or geologists. I presume the speaker is referring to obsidian hydration dating - a relative dating method that measures the microscopic hydration rim that begins forming on a freshly exposed surface of obsidian. Yet, when preparing an obsidian specimen for hydration analysis, it is not unusual to clean it in an ultrasonic bath with laboratory grade alcohol, ethanol, or methanol. Wiping the piece with consumer-grade rubbing alcohol would have absolutely no effect on the hydration rim - the only way to date an obsidian artifact. However, the finders apparently erroneously believe that isopropyl alcohol would interfere with attempts to perform obsidian-hydration dating. I cannot say for certain why the idea that this would interfere with hydration dating would be known to the original finders. And, because of the paucity of information surrounding this affair, it is difficult to determine where this piece of misinformation came from-perhaps the men were told this by a well-meaning but incorrect archaeologist. Or, perhaps something more nefarious is afoot, and the anecdote is intended as a hedge in case a hydration rim was ever measured on the piece. Herein lies the problem with the uncontrolled removal of artifacts from the ground by amateurs: The only information that we have about the original condition of the specimen comes from the people who found it, and there are no independent means of verifying their story.

The scientific process demands that we maintain a skeptical mindset of all reported findings, and that we seek to identify and evaluate multiple hypotheses to determine which (if any) is the most likely. At least two reasonable hypotheses explaining how this artifact arrived in Hawai' $i$ in recent times accommodate all of the available evidence. And there is absolutely no reason to focus solely on one hypothesis that involves prehistoric contact. However, the hypothesis laid out by Wolter is absolute, and he neglects to consider any other ideas or evidence aside from the geochemical signature of the spearpoint and its asserted findspot. But, as discussed here, there is plenty of additional information that may be brought to bear on this issue. Indeed, in my estimation there seems to be more evidence favoring a modern trans-Pacific voyage over an ancient one. I cannot prove that the spearpoint was deposited during the Harmonic Convergence (though admittedly that would make for a much-more interesting story), nor can intentional deception be ruled out. In the episode and in later blog posts, Wolter seems to make the case that intentional deception is not possible because the men who found the piece never attempted to profit from it. Yet the history of pseudoarchaeology is replete with stories of artifacts supposedly "found" by ostensibly well-meaning and honest people who may or may not have attempted to profit from their finds (Burgess, 2009; Feder, 2010, 2020; Tribble, 2009; Williams, 1991; Preston, 1999). 
Of course, I may be wrong. And these alternative hypotheses are certainly not the only two that could be offered to explain all of the available evidence; however, they do not require a series of unfounded assumptions, conflation of myriad Native peoples and their homelands, pre-Columbian trans-oceanic transportation of a shabbily made spearpoint, or the existence of a grand conspiracy. They are, put simply, simpler explanations.

\section{Conclusion}

The obsidian spearpoint found by two men in Haleakalā National Park on Maui, Hawai ' $i$ is made on Sierra de Pachuca 1 obsidian, traceable to volcanic deposits located in the Central Mexico Highlands. The piece shows numerous technological characteristics consistent with a modern tourist-trade item, and such items are available for purchase both in Mexico and via the Internet. The piece shows no evidence of having been buried or covered in mud, as reportedly was the case. No evidence of weathering can be observed on the piece. In both form and technology, the Haleakalā specimen is inconsistent with pre-Columbian tools and ceremonial productions.

The events surrounding the finding and reporting of this spearpoint highlight the dangers of uncontrolled removal of artifacts by ostensibly well-meaning laypersons, and the subsequent involvement of pseudoarchaeologists who hold minimal (if any) formal training in the science of archaeology. To be clear: unauthorized removal of cultural artifacts from public land is potentially a violation of State and/or Federal statutes. Many of the unanswered questions surrounding this spearpoint are unanswerable because the specimen was removed in an uncontrolled manner. Moreover, the involvement with and airing of a television program highlighting the removal of what might have been a legitimate archaeological artifact from Federal lands may encourage other people to pick up and remove legitimate artifacts held in the public trust, thus destroying the archaeological record and fueling pseudoarchaeological and conspiratorial claims.

After the National Park Service retook possession of the piece, Wolter in his show and in a later blog post asserted that confiscation of the specimen is evidence of some sort of conspiracy or government coverup. As he narrates in the episode: "I've seen things covered up, swept under the rug. I've seen every excuse in the world that people can think of to cover up an artifact...to try to show that this isn't real, it's fake...The fact that the National Park Service confiscated the obsidian spearpoint...tells me that it's even more important than I thought." For some conspiratorially minded people, these statements may be quite seductive.

In the eyes of this author, if there was some sort of conspiracy to hide evidence of Polynesian contact with the American continents, it must be one of the worst-kept conspiracies ever devised. In the episode Wolter interviewed at least four professional archaeologists, all of whom teach at the college level, regarding the potential for Polynesian contact in the Americas. Wolter's assertion of a cover-up hinges on obfuscation of the point that uncontrolled and unauthorized removal of items of cultural heritage, be they 50 years old or 10,000 years old, from a National Park is a violation of Federal Law, and that it is standard practice that such items will be returned to the National Park Service after removal. Here, I have made reference to numerous published articles discussing the hypothesis of contact between Native South Americans and Polynesians - a hypothesis that continues to be debated and researched by professional archaeologists. However, the Haleakalā spearpoint cannot, and should not, be considered evidence for a pre-Columbian connection between Hawai' $i$ and Native people indigenous to either North or South America. There is no reason to believe it to be evidence of contact with the Maya, the Chumash, or South Americans (as alleged by Wolter) as these people did not have access to the Pachuca obsidian source. Rather, the simplest explanation that ac- counts for a majority of evidence observed from the artifact itself, is that it was transported to Maui at some point in the recent past, and deposited in the Haleakalā crater.

\section{Acknowledgements}

I thank the staff of the University of Missouri Research Reactor and the Archaeometry Laboratory, including Steve Morris, and Cody Roush who assisted with the analysis of this specimen. Thanks to Wesley Stoner, Lee Lyman, and Dave Meltzer who provided comments and suggestions on an earlier draft of this report. I also recognize and thank the anonymous reviewers of this manuscript. You all provided helpful feedback and suggestions that I think resulted in a better product. Any errors or oversights that remain are my own.

\section{Endnotes}

1. Nearly all the information concerning the recovery and disposition of the Haleakalā specimen come from various interviews-conducted at least four years after the fact-with only two of the ten or more individuals who allegedly found the piece. This is, of course, problematic: There is no way to independently verify these statements or the chain of custody of the specimen. Here, I assume that the information provided to reporters and to America Unearthed are as close to "the facts" as is reasonably achievable.

\section{References}

Andrefsky, W., 2005. Lithics: Macroscopic Approaches to Analysis. Cambridge University Press, Cambridge.

Barker, A.W., Skinner, C.E., Shackley, M.S., Glascock, M.D., Rogers, J.D., 2002. Mesoamerican origin for an obsidian scraper from the Precolumbian Southeastern United States. Am. antiq. 67 (1), 103-108.

Boulanger, M.T., Jamison, T.R., Skinner, C., Glascock, M.D., 2007. Analysis of an obsidian biface reportedly found in the Connecticut River valley of Vermont. Archaeol. Eastern North America 35, 81-92.

Brand, R.D., 1971. The sweet potato: an exercise in methodology. In: Riley, C.L., Kelley, J.C., Pennington, C.W., Rands, R.L. (Eds.), Man Across the Sea: Problems of Pre-Columbian Contacts. University of Texas Press, Austin, pp. 343-365.

Braswell, G.E., 2010. Obsidian exchange spheres. In: Smith, M.E. (Ed.), The Postclassic Mesoamerican World. University of Utah Press, Salt Lake City, pp. 131-158.

Braswell, G.E., Andrews V, E.W., Glascock, M.D., 1994. The Obsidian Artifacts of Quelepa, El Salvador. Ancient Mesoam 5 (2), 173-192.

Burgess, D., 2009. Romans in Tucson?: The story of an archaeological hoax. J. Southwest 51 (1), 3-135.

de Camp, L. Sprague and C.C. de Camp 1972 Citadels of Mystery: Unsolved Puzzles of Archaeology, Atlantis, Stonehenge, Tintagel, and More. Fontana/Collins, Glasgow.

Carballo, D.M., 2007. Implements of state power: weaponry and martially themed obsidian production near the Moon Pyramid, Teotihuacan. Ancient Mesoam. 18 (1), 173-190.

Colavito, J., 2014a. Review of American Unearthed S02E13 “The Spearhead Conspiracy." Feb 23. Available at: http://www.jasoncolavito.com/blog/review-of-america-unearthed-s02e13-the-spearhead-conspiracy.

Colavito, J., 2014b. Newspaper: America Unearthed producers lied to Scott Wolter about spear point to create drama. Mar 7. Available at: http://www.jasoncolavito.com/ blog/newspaper-america-unearthed-producers-lied-to-scott-wolter-about-spear-point-to-create-drama.

Colavito, J., 2014c. An interview with Dr. Janet Six on the Mexican obsidian spear point found in Hawai' 'i. Mar 11. Available at: http://www.jasoncolavito.com/blog/an-interview-with-dr-janet-six-on-the-mexican-obsidian-spear-point-found-in-Hawai'i.

Colavito, J. 2020 Scott Wolter: Travel Channel Cancels "America Unearthed." Jan 2. Available at: http://www.jasoncolavito.com/blog/scott-wolter-travel-channel-cancels-america-unearthed

Cotterell, B., Kamminga, J., 1987. The Formation of Flakes. Am. antiq. 52 (4), 675-708.

Feder, K., 2010. Encyclopedia of Dubious Archaeology: From Atlantis to the Walam Olum. Greenwood, Santa Barbara, California.

Feder, K., 2020. Frauds, Myths, and Mysteries: Science and Pseudoscience in Archaeology. Oxford University Press, New York.

Finn, Christine, 1997. 'Leaving more than footprints': modern votive offerings at Chaco Canyon prehistoric site. Antiquity 71 (271), 169-178.

Ford, J.A., 1969 A Comparison of Formative Cultures in the Americas: Diffusion or the Psychic Unity of Man. Smithsonian Contributions to Anthropology, v. 11. Smithsonian Institution, Washington, D.C.

Fritze, R., 2002. Pseudoarchaeology; Precolumbian discoverers of America as a test case In: Shermer, M. (Ed.), The Skeptic Encyclopedia of Pseudoscience. ABC-CLIO, Santa Barbara, California, pp. 567-579.

Gienger, M., 2009. Healing Crystals; the A-Z Guide to 430 Gemstones. Earthdancer Books, Forres, Scotland. 
Glascock, M.D., Ferguson, J.R., 2012 Report on the analysis of obsidian source specimens by multiple analytical methods. Report submitted to Bruker Instruments. On file at MURR.

Heyerdahl, T., 1950 Kon-Tiki: Acros the Pacific by Raft. Translated by F.H. Lyon. Rand McNally, New York.

Hirth, K.G., Carballo, D.M., Dennison, M., Carr, S., Imfeld, S., Dyrdahl, E., 2019. Excavation of an obsidian craft workshop at Teotihuacan, Mexico. Ancient Mesoamerica 30: 163-179.

Ioannidis, A.G., Blanco-Portillo, J., Sandoval, K., Hagelberg, E., Miquel-Poblete, J.F., Moreno-Mayar, J.V., Rodriguez-Rodriguez, J.E., Quinto-Cortes, C.D., Auckland, K., Parks, T., Robson, K., Hill, A.V.S., Avila-Arcos, M.C., Sockell, A., Homburger, J.R., Wojcik, G.L., Barnes, K.C., Herrera, L., Berrios, S., Acuna, M., Llop, E., Eng, C., Huntsman, S., Burchard, E.G., Gignoux, C.R., Cifuentes, L., Verdugo, R.A., Moraga, M., Mentzer, A.J., Bustamante, C.D., Moreno-Estrada, A., 2020. Native American gene flow into Polynesia predating Easter Island settlement. Nature 583 (7817), 572-577.

Ivakhiv, A., 2005 Harmonic Convergence. Encyclopedia of Religion and Nature, Bron Taylor (ed.), London, Continuum, pp. 738.

Jones, T.L., Klar, K.A., 2005. Diffusionism reconsidered: linguistic and archaeological evidence for prehistoric Polynesian contact with Southern California. Am. antiq. 70 (3), 457-484.

Klar, K.A., Jones, T.L., 2005. Linguistic evidence for a prehistoric Polynesia: southern California contact event. Anthropological Linguistics 47 (4), 369-400.

Lyman, R.L., VanPool, T.L., O'Brien, M.J., 2008. Variation in North American dart points and arrow points when one or both are present. J. Archaeol. Sci. 35 (10), 2805-2812.

McKusick, M., 1986. Deciphering ancient America. In: Frazier, K. (Ed.), Science Confronts the Paranormal. Buffalo, N.Y., Prometheus, pp. 267-273.

Meggers, B.J., Evans, C., Estrada, E., 1965. Early Formative Period of Coastal Ecuador: The Valdivia and Machalilla Phases. Smithsonian Contributions to Anthropology, v. 1. Smithsonian Institution, Washington, D.C.

Muñoz-Rodríguez, P., Carruthers, T., Wood, J.R.I., Williams, B.R.M., Weitemier, K., Kronmiller, B., Ellis, D., Anglin, N.L., Longway, L., Harris, S.A., Rausher, M.D., Kelly, S., Liston, A., Scotland, R.W., 2018. Reconciling conflicting phylogenies in the origin of sweet potato and dispersal to Polynesia. Curr. Biol. 28 (8), 1246-1256.

Novick, A., Currie, A.M., McQueen, E.W., Brouwer, N.L., 2020. Kon-Tiki experiments. Philos. Sci. 87 (2), 213-236.

Odell, G.H., 2004 Lithic Analysis. Manuals in Archaeological Method, Theory and Technique. Kluwer Academic, New York.

Pignataro, A., 2014. Haleakalā and the Raiders of the Lost Spearpoint. Maui Time Weekly (HI) 17 (38), 10-11.

Ponomarenko, A.L., 2004. The Pachuca obsidian source, Hidalgo, Mexico: a geoarchaeological perspective. Geoarchaeol. Int. J. 19, 71-91.

Randi, J., 1987. Flim-Flam! Psychics, ESP, Unicorns, and Other Delusions. Prometheus Books, Buffalo, N.Y..
Rasmussen, M., Sikora, M., Albrechten, A., Korneliussen, T.S., Moreno-Mayar, J.V., Poznik, G.D., Zollikofer, C.P.E., Ponce de Leon, M.S., Allentoft, M.E., Moltke, I., Jonsson, H., Valdiosera, C., Malhi, R.S., Orlando, L., Bustamante, C.D., Stafford, T.W., Meltzer, D.J., Nielson, R., Willerslev, E., 2015. The ancestry and affiliations of Kennewick Man. Nature 523 (7561), 455-458.

Roullier, C., McKey, D.B., Lebot, V., 2013. Historical collections reveal patterns of diffusion of sweet potato in Oceania obscured by modern plant movements and recombination. Proc. Natl. Acad. Sci. U.S.A. 110, 2205-2210.

Schott, M.J., 1996. Innovation and selection in prehistory: a case study from the American Bottom. In: Odell, G.H. (Ed.), Stone Tools: Theoretical Insights into Human Prehistory. Plenum Press, New York, pp. 279-309.

Schott, M.J., 1997. Stones and shaft redux: the metric discrimination of chipped-stone dart and arrow points. Am. Antiq. 62, 86-102.

Preston, D., 1999 Woody's dream. New Yorker. Nov. 15. 75(34):80-87.

Seguin, J., 2008 Contemporary Use of Archaeological Parks: Pilgrimage and the Sacred at Stonehenge, Chaco Canyon, and Tikal. Unpublished M.A. thesis. Trent University, Peterborough, Ontario, Canada.

Speakman, R.J., 2012 Evaluation of Bruker's Tracer Family Factory Obsidian Calibration for Handheld Portable XRF Studies of Obsidian. Prepared by: Center for Applied Isotope Studies, University of Georgia. Prepared for Bruker, Kennewick, Washington.

Spence, M.W., 1996. Commodity or gift: Teotihuacán obsidian in the Maya region. Am. Antiq. 7, 21-39.

Steibing, W.H., 1984 Ancient Astronauts, Cosmic Collisions, and Other Popular Theories about Man's Past. Prometheus Books, Buffalo, New York.

Sullivan, W., 1987 New era dawns - or just a new day: Some believe Sunday marks the start of a pivotal epoch. New York Times. August 11, 1987. C3.

Thomas, D.H., 1978 Arrowheads and atlatl darts: how the stones got the shaft. American Antiquity 43: 461-472.

Thomson, V.A., Lebrasseur, O., Austin, J.J., Hunt, T.L., Burney, D.A., Denham, T., Rawlence, N.J., Wood, J.R., Gongora, J., Girdland Flink, L., Linderholm, A., Dobney, K., Larson, G., Cooper, A., 2014. Using ancient DNA to study the origins and dispersal of ancestral Polynesian chickens across the Pacific. Proc. Natl. Acad. Sci. U.S.A. 111 (13), 4826-4831.

Tribble, S., 2009. A Colossal Hoax: The Giant from Cardiff the Fooled America. Rowman and Littlefield, Lanham, Maryland.

Vanpool, T.L., 2006. The survival of Archaic technology in an agricultural world:how the atlatl and dart endured in the North American Southwest. Kiva 71 (4), 429-452.

Whittaker, J.C., 1994. Flintknapping: Making and Understanding Stone Tools. University of Texas Press, Austin.

Williams, S., 1991. Fantastic Archaeology; The Wild Side of North American Prehistory. University of Pennsylvania Press, Philadelphia.

Weisman, J., 1987. Harmonic Convergence at Mt. Shasta: New Age dawning on fewer than expected. Los Angeles Times. August 16, 1987. A38. 